\title{
The effects of different levels of irrigation water salinity and leaching on the amount and distribution pattern of soil salinity and ions in an arid region
}

\author{
H. Mansouri ${ }^{1}$, B. Mostafazadeh-Fard ${ }^{2}$ \& A. Neekabadi ${ }^{3}$ \\ ${ }^{1}$ Ab-Fan Consulting Engineers, Iran \\ ${ }^{2}$ Irrigation Department, College of Agriculture, \\ Isfahan University of Technology Iran \\ ${ }^{3}$ Department of Computer Engineering, Payame-Noor University, Iran
}

\begin{abstract}
Soil salinity is a major environmental factor limiting the productivity of agricultural lands. To determine the effects of irrigation water salinity and leaching on soil salinity and ion concentrations, a field experiment was conducted on a siltyclay soil (a typical soil of the Rudasht region, Isfahan province, Iran). The experiment consisted of three irrigation water salinity levels $(2,8$, and $12 \mathrm{dS} / \mathrm{m})$ with/without leaching levels of 4,19 , and $32 \%$ under two irrigation water management scenarios. Using factorial design, four replications for each treatment were used. The results showed that as the irrigation water salinity increased, the EC (Electrical Conductivity), $\mathrm{CO}_{3}{ }^{2-}$ (Carbon Trioxide), $\mathrm{Cl}^{-}$(Chlorine), $\mathrm{SO}_{4}{ }^{2+}$ (Sulphate), $\mathrm{Ca}$ (Calcium), Mg (Magnesium) and $\mathrm{Na}$ (Sodium) concentrations in the soil decreased significantly. The minimum and maximum values of soil salinity were 4.2 and $9.4 \mathrm{dS} / \mathrm{m}$, respectively. Irrigation management decreased salinity and soil ions and leaching decreased the amount of $\mathrm{Cl}^{-}, \mathrm{SO}_{4}{ }^{2+}$ and $\mathrm{Na}$ in soil but only the effect of irrigation management was significant in decreasing $\mathrm{CO}_{3}{ }^{2-}, \mathrm{Cl}^{-}$and $\mathrm{Na}$ values. Irrigation management was more effective than leaching in decreasing ions. As the irrigation water salinity increased, soil moisture content increased and leaching reduced soil salinity. In treatments which were irrigated with $2 \mathrm{dS} / \mathrm{m}$ water, soil salinity increased with depth. In treatments which were irrigated by $8 \mathrm{dS} / \mathrm{m}$ water, soil salinity increased to the depth of $30 \mathrm{~cm}$, decreased to the depth of $60 \mathrm{~cm}$ and then remained constant. In treatments which were
\end{abstract}


irrigated by $12 \mathrm{dS} / \mathrm{m}$ water, soil salinity increased to the depth of $30 \mathrm{~cm}$ and then decreased. Effects of irrigation water management and leaching on salt removal from soil was higher for the top soil layer as compared to the lower layers of soil. Under leaching, more salts were accumulated at the lower depths of soil. The distribution pattern of different ions was drawn by using measured data. Then the results were simulated by a calibrated SWAP (Soil, Water, Atmosphere and Plant) model. The R-squared value showed that SWAP is usable to predict soil salinity and ion amounts. This should allow users to examine efforts aimed at sustainable agricultural production and profitable yield in arid regions.

Keywords: irrigation management, soil salinity, ion, distribution pattern.

\section{Introduction}

During the last 3-4 decades, as the demand for agricultural productions increased the irrigated lands also increased by about $300 \%$. This has imposed a further increase in soil salinization and a relative decrease in crop yield [1]. Soil salinity is a major environmental factor limiting the productivity of agricultural lands. Land degradation causes soil salinity problems and affects food production [2]. This problem is not only reducing the agricultural productivity, but is also putting far reaching impacts on the livelihood strategies of small farmers [3]. Use of saline water for irrigation is a subject of increasing interest because of the increasing water requirements for irrigation and the competition between urban, industrial and agricultural sectors and moreover because of the pressure for the disposal of drainage water through reuse [4]. Due to scarcity of surface water resources, especially in arid and semi-arid regions, for supplying irrigation water for agricultural lands, the excessive discharge of the ground water with low quality has occurred which has imposed a further increase in soil salinization [1]. Salt affected soils generally have very low productivity because of dominance of the soluble salts [5]. Since the effects of salinity of irrigation water and soil on wheat yield and yield components are site specific, many researchers have investigated the adverse effects of salinity of irrigation water and soil on wheat yield and yield components for various sites and weather conditions and pointed out different results and suggestions [4]. The crop root growth and its distribution in soil are dependent on soil salt distribution pattern [1]. Specific ion effect is one of the factors that decreases yield, and it depends on ion distribution pattern [6]. It is estimated that up to $20 \%$ of irrigated lands in the world are affected somehow by different levels of salinity and sodium content. In Iran about $15 \%$ of lands, that is about 25 million ha, are suffering from this problem, including 320000 ha in Isfahan province [7]. Wheat is the most important and widely adapted cereal in Iran. Although Iran has recently been self-sufficient in its annual domestic demand for wheat, but salinity of soil and water resources, especially in arid and semi-arid regions of central parts of Iran, has effectively decreased wheat productivity. Overcoming of soil salinity and sodium content problems in arid and semi-arid regions can be achieved by managing water resources, growing salt-tolerant plants and using leaching with appropriate drainage system. Considering the fact that leaching and irrigation management are two effective and practical methods for 
improvement of saline and sodic soils, the objective of this study was to determine the effects of different irrigation water salinities, leaching and water use management on wheat yield and salt distribution in soil profile for a typical soil of an arid region in central part of Iran.

\section{Materials and methods}

The Roudasht region (32029/N, 52010/E and elevation of about $1560 \mathrm{~m}$ above mean sea level) is located in southeast of Isfahan city, central part of Iran, with about 50000 ha of salt affected soils. In this area, because of high evapotranspiration demand, low annual rainfall of less than $100 \mathrm{~mm}$, shallow groundwater table of about $3 \mathrm{~m}$, limitation of good quality river water and use of saline underground and drainage water for irrigation, the soils are losing their productivity continuously.

To achieve the objectives of this study, a typical salt affected soil of Roudasht region, silty clay loam texture, was chosen to plant wheat. Physical and chemical properties of soil were determined as shown in Tables 1 and 2, respectively. The chemical characteristics of irrigation water are shown in Table 3 . Forty field experimental plots, each plot having $5 \mathrm{~m}$ width and $20 \mathrm{~m}$ length, were used to collect data. The winter wheat (Triticum aestivum L.) cultivar $\mathbf{M}_{7318}$ was planted in each plot. About $1.25 \mathrm{~kg}$ of N.P.K fertilizer was applied with irrigation water to each plot.

The treatments consisted of three irrigation water salinity levels of 2, 8 and 12 $\mathrm{dS} / \mathrm{m}\left(\mathrm{Q}_{1}, \mathrm{Q}_{2}\right.$ and $\left.\mathrm{Q}_{3}\right)$ without leaching $\left(\mathrm{LR}_{0}\right)$ and with leaching $\left(\mathrm{LR}_{1}\right)$, including leaching levels of 4, 19 and 32 percent (the amount of additional irrigation water which applied for each irrigation). Two different irrigation water managements were used for each plot. They include irrigating the plots with the above irrigation water salinity levels from the planting to the end of the growing season (GQ) and irrigating the plots with ECiw (the electrical conductivity of irrigation water) of 2 $\mathrm{dS} / \mathrm{m}$ up to plant germination and thereafter applying the above irrigation water salinity levels (GU). The factorial design with completely randomizes blocks and four replications, for each treatment, was used. The amount of irrigation water was based on cumulative evaporation from Class A pan, using pan coefficient of 0.81 . For all treatments, the irrigation intervals were based on about $82 \mathrm{~mm}$ evaporation from the pan. To account for rainfall, the precipitation data were taken from the weather station located nearby the experimental plots. Seven irrigations were applied during the crop growing season. For each plot, soil samples were collected at the beginning, middle and end of the growing season and also before each irrigation. Soil samples were taken at depths of 0-30, 30-60 and 60-90 cm and were analyzed to determine bulk density, moisture content at field capacity, moisture content at wilting point, saturated hydraulic conductivity, saturation paste extract $\mathrm{EC}(\mathrm{ECe}), \mathrm{Ca}^{2+}, \mathrm{Mg}^{2+}, \mathrm{CO}_{3}{ }^{2-}, \mathrm{HCO}^{3-}, \mathrm{Cl}^{-}$and $\mathrm{Na}^{+}$using standard methods. 
Table 1: Physical characteristics of soil.

\begin{tabular}{|c|c|c|c|c|c|c|c|c|}
\hline $\begin{array}{c}\text { Depth } \\
(\mathrm{cm})\end{array}$ & $\begin{array}{c}\text { Clay } \\
(\%)\end{array}$ & $\begin{array}{c}\text { Silt } \\
(\%)\end{array}$ & $\begin{array}{c}\text { Sand } \\
(\%)\end{array}$ & Texture & $\begin{array}{c}\mathrm{FC} \\
(\%)\end{array}$ & $\begin{array}{c}\mathrm{WP} \\
(\%)\end{array}$ & $\begin{array}{c}\rho_{b} \\
\left(\mathrm{gr} / \mathrm{cm}^{3}\right)\end{array}$ & $\begin{array}{c}\mathrm{K} \\
(\mathrm{m} / \mathrm{day})\end{array}$ \\
\hline $0-30$ & 14 & 54 & 32 & $\begin{array}{c}\text { Silty } \\
\text { loam }\end{array}$ & 28 & 17 & 1.22 & 1.2 \\
\hline $30-40$ & 46 & 44 & 10 & $\begin{array}{c}\text { Silty } \\
\text { clay }\end{array}$ & 27 & 17 & 1.10 & 1.4 \\
\hline $40-65$ & 56 & 40 & 4 & $\begin{array}{c}\text { Silty } \\
\text { clay }\end{array}$ & 31 & 18 & 1.33 & 1.2 \\
\hline $65-5$ & 56 & 40 & 4 & $\begin{array}{c}\text { Silty } \\
\text { clay }\end{array}$ & 32 & 19 & 1.82 & 2.0 \\
\hline $75-90$ & 64 & 30 & 6 & Clay & 30 & 16 & 1.91 & 1.4 \\
\hline
\end{tabular}

Table 2: Chemical characteristics of soil.

\begin{tabular}{|c|c|c|c|c|c|c|c|c|c|}
\hline \multirow{2}{*}{$\begin{array}{c}\text { Depth } \\
(\mathrm{cm})\end{array}$} & \multirow{2}{*}{$\begin{array}{c}\mathrm{EC} \\
(\mathrm{dS} / \mathrm{m})\end{array}$} & \multicolumn{5}{|c|}{ Ions (meq/lit) } & \multirow{2}{*}{$\mathrm{HH}$} & ESP & \multirow{2}{*}{ SAR } \\
\cline { 3 - 8 } & $\mathrm{HCO}_{3}$ & $\mathrm{Cl}$ & $\mathrm{SO}_{4}$ & $\mathrm{Ca}+\mathrm{Mg}$ & $\mathrm{Na}$ & & & \\
\hline $0-30$ & 6.8 & 3.6 & 40.3 & 33.7 & 43.6 & 35.0 & 7.6 & 19.8 & 7.5 \\
\hline $30-60$ & 6.2 & 3.5 & 30.0 & 35.4 & 41.4 & 28.5 & 7.6 & 21.1 & 6.3 \\
\hline $60-90$ & 6.5 & 3.5 & 30.0 & 40.0 & 39.0 & 36.5 & 7.7 & 31.1 & 8.3 \\
\hline
\end{tabular}

Table 3: Average values of irrigation water quality for the irrigation season.

\begin{tabular}{|c|c|c|c|c|c|c|c|c|}
\hline \multirow{2}{*}{ Treat. } & \multirow{2}{*}{$\begin{array}{l}\text { Water } \\
\text { source }\end{array}$} & \multirow{2}{*}{$\begin{array}{c}\mathrm{EC} \\
(\mathrm{dS} / \mathrm{m})\end{array}$} & \multicolumn{5}{|c|}{ Ions (meq/lit) } & \multirow{2}{*}{ SAR } \\
\hline & & & $\mathrm{HCO}_{3}$ & $\mathrm{Cl}$ & $\mathrm{SO}_{4}$ & $\mathrm{Ca}+\mathrm{Mg}$ & $\mathrm{Na}$ & \\
\hline Q1 & River & 1.7 & 3.2 & 11.6 & 7.1 & 6.6 & 11.2 & 6.2 \\
\hline Q2 & Well & 9.0 & 4.9 & 68.1 & 31.8 & 32.6 & 66.9 & 16.6 \\
\hline Q3 & Drainage & 12.5 & 4.6 & 104.3 & 26.2 & 35.0 & 101.0 & 24.1 \\
\hline
\end{tabular}

\section{Results and discussion}

\subsection{Salt concentration in soil}

As shown in Table 4, the averages of soil salinity were $4.2,8.7$ and $9.4 \mathrm{dS} / \mathrm{m}$ respectively. Irrigation water salinity increased soil salinity and its affection was significant in Q2 and Q3 treatments. Although Irrigation management decreased soil salinity, it had no significant effect. On the other hand leaching had no effect on soil salinity. Previous researches proved that the minimum height of leaching water should be $30 \mathrm{~cm}$ to reduce soil salinity in this area, while it was just $5 \mathrm{~cm}$ in 
this study. Summary of the statistical analysis of the treatments showed that the effect of irrigation water salinity and irrigation management on salt concentration in soil were significant at $\mathrm{P}<0.001$ and the effect of $\mathrm{LR}, \mathrm{Q}^{*} \mathrm{GU}, \mathrm{Q}^{*} \mathrm{LR}, \mathrm{GU}^{*} \mathrm{LR}$ and $\mathrm{Q}^{*} \mathrm{GU} \mathrm{U}^{*} \mathrm{LR}$ (where $\mathrm{LR}=$ leaching, $\mathrm{Q}=$ irrigation water salinity and $\mathrm{GU}=$ irrigation management) were not significant.

\subsection{Ions concentration in soil}

As shown in Table 4, irrigation water salinity increased significantly ions concentration in soil, irrigation management decreased soil ions and leaching decreased the amount of $\mathrm{Cl}^{-}, \mathrm{SO}_{4}{ }^{2+}$ and $\mathrm{Na}$ in soil but only the effect of irrigation management was significant in decreasing $\mathrm{CO}_{3}{ }^{2-}, \mathrm{Cl}^{-}$and $\mathrm{Na}$ values. Irrigation management was more effective than leaching in decreasing ions. Mean values for soil chemical parameters in different treatments and summary of the statistical analysis of the treatments are shown in Table 4.

\subsection{Soil moisture content}

As shown in Fig. 2, soil moisture content increased by increasing the irrigation water salinity. In addition soil moisture content in depth of 30-60 cm was much more than the depth of $0-30 \mathrm{~cm}$ in both treatments with leaching and without leaching. On the other hand, irrigation management didn't have any effect on increasing or decreasing of soil moisture content.

\subsection{Salt distribution pattern}

The salt distribution patterns in soil are shown in Figs 3, 4 and 5 for irrigation water salinities of 2,8 and $12 \mathrm{dS} / \mathrm{m}$, respectively. For irrigation water salinity of 2 $\mathrm{dS} / \mathrm{m}$, there is an increase in soil salinity as the soil depth increases (Fig. 3). For this treatment, leaching decreases the soil salinity, especially at the upper section of the soil zone. This result is consistent with the results obtained by Oster et al. [8].

For irrigation water salinity of $8 \mathrm{dS} / \mathrm{m}$, soil salinity increases slightly down to the soil depth of $30 \mathrm{~cm}$, decreases significantly in depth of $60 \mathrm{~cm}$ and remains constant down to the depth of $90 \mathrm{~cm}$ (Fig. 4). Leaching decreases the salinity in soil profile as compared to the non-leaching treatment. The comparison of $\mathrm{Q}_{2} \mathrm{GQLR}_{0}$ and $\mathrm{Q}_{2} \mathrm{GULR}_{0}$ in Fig. 4 shows that irrigation management (GU) causes a decrease in soil salinity with depth. The comparison of $\mathrm{Q}_{2} \mathrm{GQLR}_{1}$ and $\mathrm{Q}_{2} \mathrm{GULR}_{1}$ also shows similar results.

For irrigation water salinity of $12 \mathrm{dS} / \mathrm{m}$, soil salinity increases down to the depth of $30 \mathrm{~cm}$, and then decreases to depth of $90 \mathrm{~cm}$ (Fig. 5). Leaching decreases salinity in the soil profile as compared to the non-leaching treatment. The comparison of $\mathrm{Q}_{3} \mathrm{GQLR}_{0}$ and $\mathrm{Q}_{3} \mathrm{GULR}_{0}$ in Fig. 5 shows that irrigation management $(\mathrm{GU})$ causes a decrease in the salinity down to the soil depth of 50 $\mathrm{cm}$. Comparison of $\mathrm{Q}_{3} \mathrm{GQLR}_{1}$ and $\mathrm{Q}_{3} \mathrm{GULR}_{1}$ also shows similar results. 
Table 4: Comparison of soil components for different treatments.

\begin{tabular}{|c|c|c|c|c|c|c|c|c|}
\hline \multicolumn{9}{|c|}{ Soil chemical parameters } \\
\hline Treatment & $\begin{array}{c}\text { EC (Water) } \\
(\mathrm{dS} / \mathrm{m})\end{array}$ & $\begin{array}{c}\mathrm{EC}_{\mathrm{e}} \\
(\mathrm{dS} / \mathrm{m})\end{array}$ & $\begin{array}{c}\mathrm{CO}_{3}{ }^{2-} \\
\text { (Meq/lit) }\end{array}$ & $\begin{array}{c}\mathrm{Cl}^{-} \\
\text {(Meq/lit) }\end{array}$ & $\begin{array}{c}\mathrm{SO}_{4}{ }^{2+} \\
\text { (Meq/lit) }\end{array}$ & $\begin{array}{c}\mathrm{Ca}, \mathrm{Mg} \\
\text { (Meq/lit) }\end{array}$ & $\begin{array}{c}\mathrm{Na} \\
(\mathrm{Meq} / \mathrm{lit})\end{array}$ & \\
\hline \multicolumn{9}{|c|}{ Mean values for soil components in different treatments } \\
\hline $\mathrm{Q}_{1} \mathrm{GQLR}_{0}$ & 2 & $4.5 \mathrm{~b}$ & $2.1 \mathrm{bc}$ & $16.0 \mathrm{c}$ & $31.3 \mathrm{de}$ & $27.3 \mathrm{e}$ & $23.1 \mathrm{e}$ & \\
\hline $\mathrm{Q}_{1} \mathrm{GQLR}_{1}$ & 2 & $3.9 \mathrm{a}$ & $1.3 \mathrm{~d}$ & $14.6 \mathrm{c}$ & $28.8 \mathrm{e}$ & $26.0 \mathrm{e}$ & $19.8 \mathrm{e}$ & \\
\hline $\mathrm{Q}_{2} \mathrm{GQLR}_{0}$ & 8 & $9.3 \mathrm{a}$ & $1.8 \mathrm{~cd}$ & $58.3 \mathrm{a}$ & $42.4 \mathrm{a}$ & $40.3 \mathrm{bc}$ & $63.3 \mathrm{ab}$ & \\
\hline $\mathrm{Q}_{2} \mathrm{GQLR}_{1}$ & 8 & $9.1 \mathrm{a}$ & $2.0 \mathrm{bc}$ & $57.0 \mathrm{a}$ & $36.1 \mathrm{bc}$ & $40.3 \mathrm{bc}$ & $55.8 \mathrm{bcd}$ & \\
\hline $\mathrm{Q}_{2} \mathrm{GULR}_{0}$ & 8 & $7.9 \mathrm{a}$ & $1.8 \mathrm{~cd}$ & $47.0 \mathrm{a}$ & $34.3 \mathrm{~cd}$ & $35.6 \mathrm{~d}$ & $48.5 \mathrm{~d}$ & \\
\hline $\mathrm{Q}_{2} \mathrm{GULR}_{1}$ & 8 & $8.6 \mathrm{a}$ & $1.8 \mathrm{~cd}$ & $46.3 \mathrm{~b}$ & $40.3 \mathrm{ab}$ & $37.3 \mathrm{~cd}$ & $52.1 \mathrm{~cd}$ & \\
\hline $\mathrm{Q}_{3} \mathrm{GQLR}_{0}$ & 12 & $9.5 \mathrm{a}$ & $2.5 \mathrm{ab}$ & $63.0 \mathrm{a}$ & $44.4 \mathrm{a}$ & $39.6 \mathrm{bc}$ & $66.6 \mathrm{a}$ & \\
\hline $\mathrm{Q}_{3} \mathrm{GQLR}_{1}$ & 12 & $9.1 \mathrm{a}$ & $2.8 \mathrm{a}$ & $59.6 \mathrm{a}$ & $40.2 \mathrm{ab}$ & $40.6 \mathrm{~b}$ & $63.1 \mathrm{ab}$ & \\
\hline $\mathrm{Q}_{3} \mathrm{GULR}_{0}$ & 12 & $9.4 \mathrm{a}$ & $2.2 \mathrm{bc}$ & $58.6 \mathrm{a}$ & $43.7 \mathrm{a}$ & $44.0 \mathrm{a}$ & $61.6 \mathrm{ab}$ & \\
\hline $\mathrm{Q}_{3} \mathrm{GULR}_{1}$ & 12 & $9.5 \mathrm{a}$ & $2.0 \mathrm{bc}$ & $61.6 \mathrm{a}$ & $42.8 \mathrm{a}$ & $41.3 \mathrm{ab}$ & $58.8 \mathrm{abc}$ & \\
\hline \multicolumn{9}{|c|}{ Mean values for soil components for each treatment } \\
\hline $\mathrm{Q}_{1}$ & \multirow{3}{*}{$\begin{array}{c}\text { Salinity } \\
\text { comparison }\end{array}$} & $4.2 \mathrm{~b}$ & $1.7 \mathrm{~b}$ & $15.3 \mathrm{c}$ & $30.0 \mathrm{c}$ & $26.6 \mathrm{c}$ & $21.4 \mathrm{c}$ & \\
\hline $\mathrm{Q}_{2}$ & & $8.7 \mathrm{a}$ & $1.9 \mathrm{~b}$ & $52.1 \mathrm{~b}$ & $38.3 \mathrm{~b}$ & $38.4 \mathrm{~b}$ & $54.9 \mathrm{~b}$ & \\
\hline $\mathrm{Q}_{3}$ & & $9.4 \mathrm{a}$ & $2.4 \mathrm{a}$ & $60.7 \mathrm{a}$ & $42.8 \mathrm{a}$ & $41.4 \mathrm{a}$ & $62.5 \mathrm{a}$ & \\
\hline GU & \multirow{2}{*}{$\begin{array}{c}\text { Management } \\
\text { comparison }\end{array}$} & $8.9 \mathrm{a}$ & $2.0 \mathrm{~b}$ & $53.4 \mathrm{~b}$ & $40.2 \mathrm{a}$ & $39.5 \mathrm{a}$ & $55.3 \mathrm{~b}$ & \\
\hline GQ & & $9.3 \mathrm{a}$ & $2.3 \mathrm{a}$ & $59.5 \mathrm{a}$ & $40.8 \mathrm{a}$ & $40.2 \mathrm{a}$ & $62.2 \mathrm{a}$ & \\
\hline $\mathrm{LR}_{1}$ & \multirow{2}{*}{$\begin{array}{l}\text { Leaching } \\
\text { comparison }\end{array}$} & $9.1 \mathrm{a}$ & $2.1 \mathrm{a}$ & $56.1 \mathrm{a}$ & $39.8 \mathrm{a}$ & $39.9 \mathrm{a}$ & $57.4 \mathrm{a}$ & \\
\hline $\mathrm{LR}_{0}$ & & $9.1 \mathrm{a}$ & $2.1 \mathrm{a}$ & $56.7 \mathrm{a}$ & $41.2 \mathrm{a}$ & $39.9 \mathrm{a}$ & $60.0 \mathrm{a}$ & \\
\hline \multicolumn{9}{|c|}{ Summary of the statistical analysis of the treatments } \\
\hline S.O.V* & $\mathrm{df}$ & & & & & & & \\
\hline Q & 2 & $229.7^{* * *}$ & $4.6^{* * *}$ & $17120.2^{* * *}$ & $1304.8^{* * *}$ & $1739.4^{* * *}$ & $14052.5^{* * *}$ & \\
\hline GU & 1 & $46.3^{* * *}$ & $0.4^{\mathrm{n} . \mathrm{s}}$ & $2149.3^{* * *}$ & $265.9^{* *}$ & $429.3^{* * *}$ & $1275.7^{* * *}$ & \\
\hline LR & 1 & $0.37^{\text {n.s }}$ & $0.5^{\mathrm{n} . \mathrm{s}}$ & $16.1^{\text {n.s }}$ & $75.5^{\text {n.s }}$ & $2.1^{\mathrm{n}, \mathrm{s}}$ & $219.7^{\mathrm{n} . \mathrm{s}}$ & \\
\hline $\mathrm{Q} * \mathrm{GU}$ & 2 & $0.0^{\text {n.s }}$ & $3.25^{* * *}$ & $0.0^{\text {n.s }}$ & $0.0^{\text {n.s }}$ & $0.0^{\mathrm{n} . \mathrm{s}}$ & $6.7^{\mathrm{n} . \mathrm{s}}$ & \\
\hline $\mathrm{Q} * \mathrm{LR}$ & 2 & $1.37^{\mathrm{n} . \mathrm{s}}$ & $1.84^{* *}$ & $3.4^{\mathrm{n} . \mathrm{s}}$ & $20.6^{\mathrm{n} . \mathrm{s}}$ & $12.6^{\mathrm{n} . \mathrm{s}}$ & $6.2^{\mathrm{n} . \mathrm{s}}$ & \\
\hline GU * LR & 1 & $4.49^{\text {n.s }}$ & $0.0^{\mathrm{n} . \mathrm{s}}$ & $72.2^{\text {n.s }}$ & $339.4^{* * *}$ & $1.1^{\mathrm{n} . \mathrm{s}}$ & $197.1^{\mathrm{n} . \mathrm{s}}$ & \\
\hline $\mathrm{Q}^{*} \mathrm{GU} *$ & 2 & $0.0^{\text {n.s }}$ & $1.0^{\text {n.s }}$ & $49.4^{\text {n.s }}$ & $146.3^{*}$ & $47.5^{*}$ & $178.6^{\text {n.s }}$ & \\
\hline
\end{tabular}

Alphabets (a, b, c, d and e) show the statistically groups.

* Source of variations.

${ }_{* * *}$,**, * and n.s significant at $\mathrm{P}<0.001, \mathrm{P}<0.01, \mathrm{P}<0.05$ and non-significant, respectively. df: degrees of freedom.

In each column the values followed by at least one common character are not statistically different at 5\% probability level. 


\begin{tabular}{|c|}
\hline O \\
\hline O \\
\hline 己્0 \\
\hline 己 \\
\hline O \\
\hline O \\
\hline 己ֶ) \\
\hline 己 \\
\hline O \\
\hline og \\
\hline શ્o \\
\hline ?્0 \\
\hline O \\
\hline og \\
\hline ? \\
\hline Dֶ \\
\hline O \\
\hline O \\
\hline O \\
\hline og \\
\hline
\end{tabular}


40 Sustainable Irrigation and Drainage V

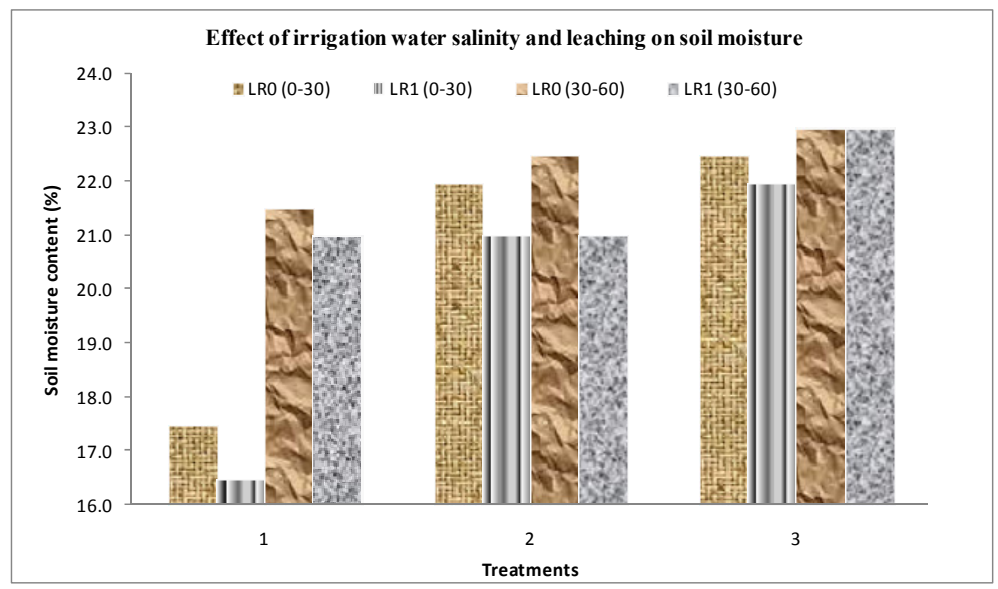

Figure 2: Effect of irrigation water salinity and leaching on soil moisture.

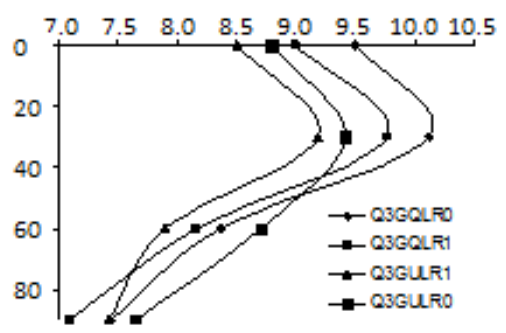

Figure 3: Salt distribution pattern for $\mathrm{Q}_{1}$.

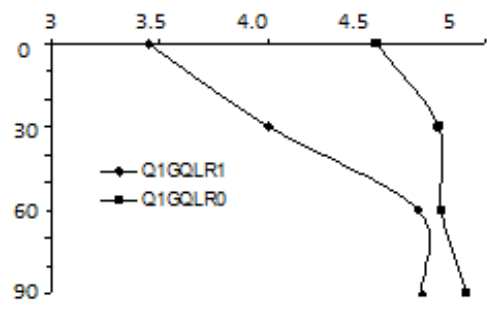

Figure 5: Salt distribution pattern for $\mathrm{Q}_{3}$.

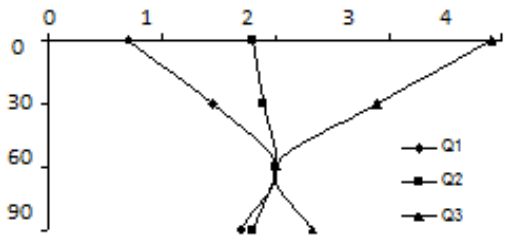

Figure 4: Salt distribution pattern for $\mathrm{Q}_{2}$.

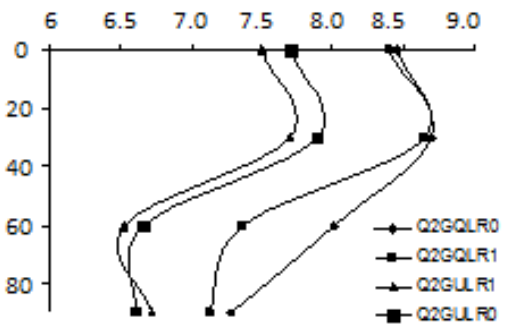

Figure 6: Salt distribution pattern for $\mathrm{CO}_{32}$. 


\subsection{Ion distribution pattern}

Ion distribution pattern in soil for different irrigation water salinities are shown in Figs. 6-10. For irrigation water salinity of $2 \mathrm{dS} / \mathrm{m}$, the value of bicarbonate ion increases to soil depth of $60 \mathrm{~cm}$, and then remains constant (Fig. 6). For irrigation water salinity of $8 \mathrm{dS} / \mathrm{m}$, the value of bicarbonate ion remains constant through the soil profile. For irrigation water salinity of $12 \mathrm{dS} / \mathrm{m}$, the value of bicarbonate ion decreases down to the depth of $60 \mathrm{~cm}$, and then remains constant. For irrigation water salinity of $2 \mathrm{dS} / \mathrm{m}$, the value of chloride increases through the soil profile (Fig. 7). For irrigation water salinities of $8 \mathrm{dS} / \mathrm{m}$ and $12 \mathrm{dS} / \mathrm{m}$ the value of chloride ion decreases down to the soil depth of $60 \mathrm{~cm}$, and then remains constant.

For irrigation water salinity of $2 \mathrm{dS} / \mathrm{m}$, the value of sulphate ion increases down the soil depth of $60 \mathrm{~cm}$, and then remains constant (Fig. 8). For irrigation water salinity of $8 \mathrm{dS} / \mathrm{m}$, the value of sulphate ion decreases slightly through the soil profile. For irrigation water salinity of $12 \mathrm{dS} / \mathrm{m}$, the value of sulphate ion remains constant throughout the soil profile.

For irrigation water salinity of $2 \mathrm{dS} / \mathrm{m}$, the value of calcium and magnesium ions increases down the soil depth of $60 \mathrm{~cm}$, and then decreases (Fig. 9). For irrigation water salinity of $8 \mathrm{dS} / \mathrm{m}$, the value of calcium and magnesium ions remains nearly constant throughout the soil profile. For irrigation water salinity of $12 \mathrm{dS} / \mathrm{m}$, the value of calcium and magnesium ions decreases almost linearly through the soil profile.

For irrigation water salinity of $2 \mathrm{dS} / \mathrm{m}$, the value of sodium ion increases nearly linearly throughout the soil profile (Fig. 10). For irrigation water salinity of 8 $\mathrm{dS} / \mathrm{m}$, the value of sodium ion decreases down the soil depth of $60 \mathrm{~cm}$, and then remains constant. For irrigation water salinity of $12 \mathrm{dS} / \mathrm{m}$, the value of sodium ion decreases through the soil profile.

The above results show that chemical interactions in soil under various irrigation water salinities cause different ion distribution patterns in soil profile. The effects of specific ions on reduction of crop yield (wheat in this experiment) needs further study.

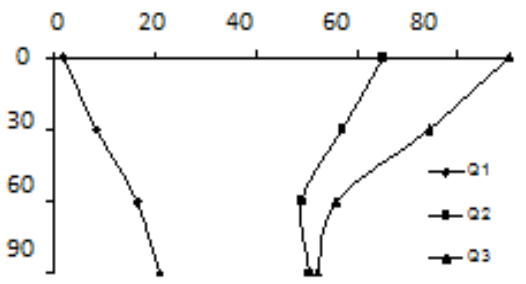

Figure 7: Salt distribution pattern for $\mathrm{Cl}^{-}$.

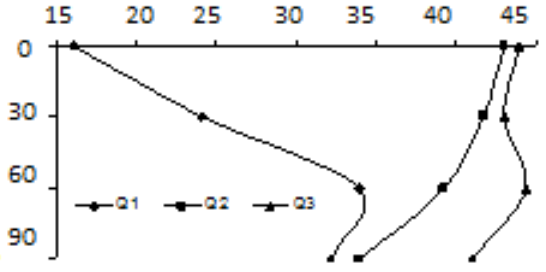

Figure 8: Salt distribution pattern for $\mathrm{SO}_{4}{ }^{2+}$. 


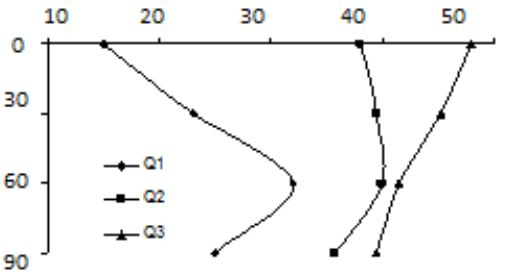

Figure 9: Salt distribution pattern for $\mathrm{Ca}, \mathrm{Mg}$.

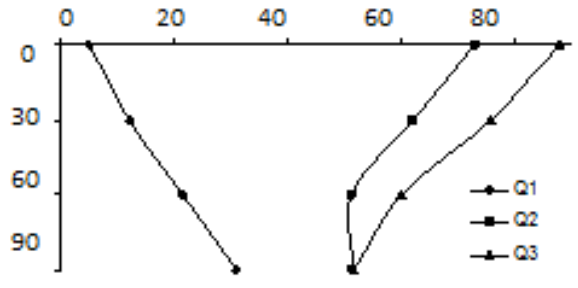

Figure 10: Salt distribution pattern for $\mathrm{Na}$.

\subsection{Soil salinity simulation}

The SWAP model, which was developed by researchers at both the DLO Winand Staring Centre and Wageningen Agricultural University, was used to simulate yield for the field conditions using the collected data. The model contains five submodels of METEO, CROP, SOIL, IRRIGATION, and TIMER. Each sub-model receives the related input data and analyses it and sends the results to the main program. In sub-model SOIL, SWAP employs Richards' equation for soil water movement. Due to its physical bases, the Richards' equation allows the use of soil hydraulic function data bases and simulation of all kind of scenario analysis. The soil hydraulic functions are described by the analytical expressions or by tabular values. Root water extraction at various soil depths is calculated from potential transpiration, root length density and possible reductions due to wet, dry, or saline conditions.

The calibrated SWAP (Soil, Water, Atmosphere and Plant) model was used to simulate soil salinity and salt and ions distribution pattern for the study area. The comparison between the model prediction and actual soil salinity data for different treatments and also the simulated equation of the model for soil salinity showed that there is a reasonable agreement between the model prediction and actual soil salinity data, which means that the model is able to predict soil salinity for saline soil conditions. Similar results were also obtained by other researchers for different soils and field conditions and they showed that the SWAP model could reasonably predict soil salinity. But the simulated result for ions distribution pattern was not acceptable.

The input data such as soil surface layer hydraulic characteristics, maximum air temperature, leaf area index, root depth, irrigation water amount and irrigation water salinity were obtained and applied to the above five sub-models and the model was run. The sensitivity of the model to the input parameters was determined, the model was calibrated for the field conditions and the simulation results of yield for each treatment was compared with the field measurements and the statistical correlations were calculated. The soil salinity parameters also were applied to the model for each treatment and the model predictions were compared with the field data.

Further information about the model, input data and the functions that are used in the model are given at the website www.alterra.nl/models/swap. 


\section{Conclusions}

The proper irrigation management and soil salt leaching decreases soil salinity and increases wheat yield. The quality of irrigation water influences salt and ion distribution pattern in soil. Effects of irrigation water salinity, irrigation management and leaching on salt removal from the soil profile are higher for the top layer soil as compared to the lower layers of soil. The interaction of irrigation management and leaching can be used as an effective tool to manage soils in arid regions in order to reduce soil salinity and increase crop yield. The parameters of linear relationship between yield decrement and soil salinity are site specific.

\section{Acknowledgements}

This research was funded by Isfahan University of Technology, Isfahan Agricultural and Natural Resources Research Center and Ab-Fan consulting engineers. This assistance is gratefully acknowledged.

\section{References}

[1] Poustini, K., Siosemardeh, A., 2004. Ion distribution in wheat cultivars in response to salinity stress. Field Crops Res. 85, 125-133.

[2] Sharma, D. P., Rao, K. V. G. K., 1998. Strategy for long term use of saline drainage water for irrigation in semi-arid regions. Soil and Tillage Research, 48(4), 287-295.

[3] Tanwir, F., Saboor, A., Nawaz, N., 2003. Soil salinity and the livelihood strategies of small farmers: A case study in Faisalabad district, Punjab, Pakistan. Int. J. Agric. Biol. 5(4), 440-441.

[4] Katerji, N., Van Hoom, J. W., Hamdy, A., Mastrorilli, M., 2000. Salt tolerance classification of crops according to soil salinity and to water stress day index. Agric. Water Manage. 43(1), 99-109.

[5] Akram, M., Hussain, M., Akhtar, Sh., Rasul, E., 2002. Impact of NaCl salinity on yield components of some wheat accessions/varieties. Int. J. Agric. Biol. 4(1), 156-158.

[6] Ashraf, M., Leary, J. W. O., 1996. Responses of newly developed salt-tolerant genotype of spring wheat to salt stress. 1. Yield components and ion distribution. J. of Agron. Crop Sci., 176, 91-101.

[7] Feizi, M., 1993. Considering the effect of water quality and quantity on desalinization of Isfahan Roudasht Soils. Technical Research Report, Isfahan Agricultural and Natural Resources Research Center, Isfahan, Iran. 8(1), 1634.

[8] Oster, J. D., Hoffman, G. J., Robinson, F. E., 1984. Management alternatives: crop, water and soil. Calif. Agric. 38, 29-32. 